\title{
A COMPARISON OF THE GASTROINTESTINAL TRACT IN GERM-FREE AND CONVENTIONAL MICE FED AN AMINO ACID MIXTURE OR PURIFIED WHOLE-EGG PROTEIN
}

\author{
Masanori YAMANAKA, Tatsuji NomURA, ${ }^{1}$ Junko ToKIOKA, \\ and Masao KAMETAKA ${ }^{2}$ \\ ${ }^{1}$ Central Institute for Experimental Animals, 1430 Nogawa, \\ Takatsu-ku, Kawasaki 213, Japan \\ ${ }^{2}$ Kyoritsu Women's University, 2-1 Hitotsubashi 2-chome, \\ Chiyoda-ku, Tokyo 101, Japan \\ (Received February 9, 1980)
}

\begin{abstract}
Summary An amino acid mixture $\operatorname{diet}(\mathrm{AA})$ simulated with purified whole-egg protein and a purified whole-egg protein $\operatorname{diet}(\mathrm{WE})$ were given to ICR strain male germ-free(GF) and conventional(CV) mice for three weeks from five to eight weeks of age. All mice were killed at eight weeks of age and the gastrointestinal tracts were removed. The lengths of the small intestine were measured and six parts, i.e., the stomach; upper, middle and lower parts of the small intestine; cecum; and colon and rectum were separated, and each part (with contents) was weighed immediately. The contents were removed from each part by washing with distilled water. For the gut without contents, only total nitrogen(TN) was estimated and for the gut contents, TN, protein nitrogen(PN) and waterinsoluble nitrogen(WIN) were estimated. The fresh weight of cecum with contents per $100 \mathrm{~g}$ of body weight of GF mice fed on AA diet, $2.07 \pm 0.11 \mathrm{~g}$ (mean $\pm \mathrm{SE})$, was lighter than that of GF mice fed on WE diet, which was $4.51 \pm 0.28 \mathrm{~g}$. The weight and length of the small intestine of AA diet groups were smaller than those of WE diet group. TN and PN(mg) in whole gut contents per $100 \mathrm{~g}$ of body weight in the WE diet group were higher than those in the AA diet group and high TN and PN were observed in GF mice. The PN per TN and WIN per PN of gut contents were affected more by the presence of the flora than by the difference in diets, and CV mice showed high values. The TN of the intestinal tract excluding contents showed no differences in GF and CV mice fed on either diet.
\end{abstract}

Keywords germ-free mice, gastrointestinal tract, gut contents, amino acids, purified whole-egg protein, influence of intestinal microbes

${ }^{1}$ 山中聖敬, 野村達次, ${ }^{2}$ 時岡淳子, 亀高正夫 
It is commonly known that in germ-free(GF) rodents or rabbits, the cecum, in particular, becomes greatly enlarged. However, the reasons for this are still not understood. If GF rodents or rabbits are conventionalized, the cecum becomes almost the same size as that of conventional(CV) rodents or rabbits in a short period of time. Intestinal microbes are undoubtedly responsible for this phenomenon, but it is not yet clear what kinds of microbe play a role in this.

The authors have already reported on the relationship between intestinal microbes and nutrition of mice using GF, gnotobiotic and CV mice (1-10). The purpose of this investigation was to make clear the influence of the absence of intestinal microbes or differences in nitrogen $(N)$ sources of diets on the appearance of the gastrointestinal tract or $\mathrm{N}$ of gut contents in mice.

\section{MATERIALS AND METHODS}

Diets. Mice were given an autoclaved CL-2 diet until five weeks of age and were thereafter fed on an amino acid mixture $\operatorname{diet}(\mathrm{AA})$ or purified whole-egg protein $\operatorname{diet}(\mathrm{WE})$ for three weeks (Table 1). These diets contained the same levels of $\mathrm{N}$ and were sterilized by $5 \mathrm{Mrad}$ of irradiation with ${ }^{60} \mathrm{Co}$, and water was autoclaved. Diets and water were given ad libitum. The amino acid mixture was prepared with the same amino acid composition as purified whole-egg protein(11). The differences in the amounts of the amino acid mixture and purified whole-egg protein were arranged by adding corn starch. The same quantitative levels of corn oil, cellulose powder, salt mixture, and vitamin mixture were used as in previous reports $(9,10)$.

Animals. ICR strain male GF and CV mice were reared in plastic rearing cages with wire mesh stainless steel floors (three or four mice per cage). Six GF and seven $\mathrm{CV}$ mice in the AA diet group (AAGF, AACV) and six GF and CV mice in the WE diet group (WEGF, WECV) were given the AA or WE diet for three weeks from five to eight weeks of age. GF mice were reared in vinyl isolators, and CV mice were kept in an open animal room at a temperature of $23 \pm 2^{\circ} \mathrm{C}$ and a relative humidity of $50-70 \%$. All mice were killed (at $10 \mathrm{AM}$ ) by etherization at eight weeks of age. The gastrointestinal tracts were removed and the length of the small intestine was measured. The gastrointestinal tracts were separated into six parts, i.e., the stomach; upper, middle, and lower part of the small intestine; cecum; and colon and rectum. After measurement of fresh weights (with contents) of each part, contents were washed out with distilled we ter. The gastrointestinal tracts and gut contents were immediately stored at $-20^{\circ} \mathrm{C}$ until analysis.

Analyses. Total N (TN) of the gastrointestinal tract and contents was estimated, and protein $\mathrm{N}(\mathrm{PN})$ and water-insoluble $\mathrm{N}$ (WIN) of the gut contents were estimated. $\mathrm{N}$ was estimated by the semi-micro Kjeldahl method. PN estimation was made by the Barnstein method. For WIN estimation, the samples were filtered using filter paper (Toyo No 5A) and $\mathrm{N}$ of residual matter on the paper was taken as the WIN in the gut contents. 
Table 1. Composition of diets.

\begin{tabular}{lcc}
\hline & $\begin{array}{c}\text { AA } \\
(\mathrm{g})\end{array}$ & $\begin{array}{c}\text { WE } \\
(\mathrm{g})\end{array}$ \\
\hline Amino acid mixture $^{\mathrm{a}}$ & 11.9 & - \\
Purified whole-egg protein $^{\mathrm{b}}$ & - & 10.6 \\
Corn starch $_{\text {Corn oil }}$ & 70.1 & 71.4 \\
Cellulose powder $_{\text {Salt mixture }}^{\mathrm{c}}$ & 8.0 & 8.0 \\
Vitamin mixture $^{\mathrm{d}}$ & 4.0 & 4.0 \\
& 4.0 & 4.0 \\
\hline
\end{tabular}

AA, diet using amino acid mixture as nitrogen source; WE, diet using purified wholeegg protein as nitrogen source.

a Amino acid mixture: L-histidine- $\mathrm{HCl}, 361 \mathrm{mg}$; L-isoleucine, $639 \mathrm{mg}$; L-leucine, $997 \mathrm{mg}$; L-lysine-HCl, $978 \mathrm{mg}$; L-methionine, $381 \mathrm{mg}$; L-cystine, $226 \mathrm{mg}$; L-phenylalanine, $611 \mathrm{mg}$; L-tyrosine, $470 \mathrm{mg}$; L-threonine, $534 \mathrm{mg}$; L-valine, $743 \mathrm{mg}$; Ltryptophan, $164 \mathrm{mg}$; L-arginine- $\mathrm{HCl}, 862 \mathrm{mg}$; L-aspartic acid, $890 \mathrm{mg}$; L-asparagine, $222 \mathrm{mg}$; L-serine, $852 \mathrm{mg}$; L-glutamic acid, $1,183 \mathrm{mg}$; L-glutamine, $296 \mathrm{mg}$; Lproline, $444 \mathrm{mg}$; glycine, $374 \mathrm{mg}$; L-alanine, $661 \mathrm{mg}$ per $100 \mathrm{~g}$ of diet. (Amino acids provided by the Kyowa Hakko Kogyo, Co., Ltd., Tokyo)

b Provided by Taiyo Foods, Co., Ltd., Yokkaichi.

c Salt mixture: sodium chloride, $139.3 \mathrm{~g}$; potassium biphosphate, $389.0 \mathrm{~g}$; magnesium sulfate, anhydrous, $57.3 \mathrm{~g}$; calcium carbonate, $381.4 \mathrm{~g}$; ferrous sulfate, $27.0 \mathrm{~g}$; manganese sulfate, $4.01 \mathrm{~g}$; potassium iodide, $0.79 \mathrm{~g}$; zinc sulfate, $0.548 \mathrm{~g}$; cupric sulfate, $0.477 \mathrm{~g}$; cobalt chloride, $0.023 \mathrm{~g}$. (U.S. Pharmacopeia XVIII)

d Vitamin mixture: vitamin A, 1,000 IU; vitamin $D_{3}, 100 \mathrm{IU}$; DL- $\alpha$-tocopherol, $10 \mathrm{IU}$; vitamin $\mathrm{K}_{3}, 0.5 \mathrm{mg}$; riboflavin, $1.0 \mathrm{mg}$; thiamine, $0.5 \mathrm{mg}$; pyridoxine, $0.4 \mathrm{mg}$; pantothenic acid, $4.0 \mathrm{mg}$; niacin, $4.0 \mathrm{mg}$; choline chloride, $200 \mathrm{mg}$; inositol, $25 \mathrm{mg}$; para-aminobenzoic acid, $10 \mathrm{mg}$; vitamin $\mathrm{B}_{12}, 2 \mu \mathrm{g}$; biotin, $0.02 \mathrm{mg}$; folic acid, $0.2 \mathrm{mg}$. Add sufficient cellulose to make 1 g. (J. A. Campbell: Method for determination of PER and NPR)

\section{RESULTS}

The body weights in the experimental period are shown in Table 2 . The body weight gains of GF and CV mice in the initial week showed almost the same values for both diets, but thereafter WEGF and CV mice showed lower values than those of AA diet fed mice. The food intake was not measured in this experiment but the diets were given ad libitum.

The fresh weights of the gastrointestinal tract (with contents) per $100 \mathrm{~g}$ of body weight are shown in Table 3 . The weight and the length of the small intestine of WEGF mice were greater $(p<0.02)$ than those of other mice except for the weight of the small intestine of WECV mice. The cecal weights per $100 \mathrm{~g}$ of body weight and per $\mathrm{g}$ of small intestine of WEGF mice were higher $(p<0.05)$ than those of the other mice. The weight of the whole intestine of WEGF mice was 
Table 2. Body weight in the experimental period in germ-free and conventional mice fed an amino acid mixture or purified whole-egg protein.

\begin{tabular}{lcccccc}
\hline \multirow{2}{*}{ Diets } & \multicolumn{2}{c}{ AA } & & \multicolumn{2}{c}{ WE } \\
\cline { 2 - 3 } \cline { 5 - 6 } \cline { 5 - 6 } & GF & CV & & GF & CV \\
\hline Number of mice & 6 & 7 & & 6 & 6 \\
& $(\mathrm{~g})$ & $(\mathrm{g})$ & & $(\mathrm{g})$ & $(\mathrm{g})$ \\
Five weeks of age & $20.5 \pm 0.7^{\mathrm{a}}$ & $25.5 \pm 0.3$ & & $20.9 \pm 0.3$ & $25.6 \pm 0.2$ \\
Six weeks of age & $24.5 \pm 0.7$ & $29.1 \pm 0.5$ & & $25.1 \pm 0.7$ & $27.8 \pm 0.3$ \\
Seven weeks of age & $26.9 \pm 0.7$ & $30.4 \pm 0.7$ & & $24.8 \pm 0.5$ & $27.6 \pm 0.4$ \\
Eight weeks of age & $28.9 \pm 0.6$ & $31.9 \pm 0.8$ & & $24.7 \pm 0.4$ & $27.9 \pm 0.5$ \\
\hline
\end{tabular}

${ }^{a}$ Means \pm SE. GF, germ-free mice; CV, conventional mice. For abbreviations, see Table 1 .

Table 3. Fresh weight of gastrointestinal tracts (with contents) and length of small intestine in germ-free and conventional mice fed an amino acid mixture or purified whole-egg protein.

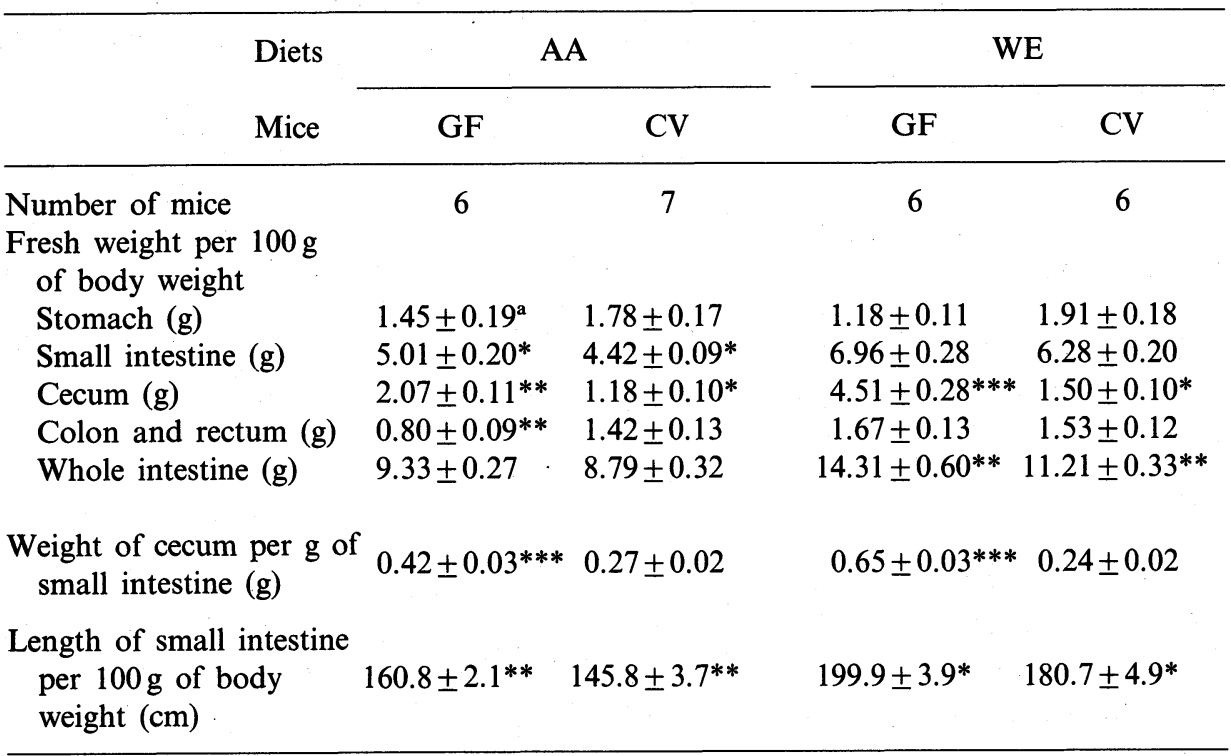

${ }^{a}$ Means \pm SE. ${ }^{*} p<0.05,{ }^{* *} p<0.01,{ }^{* * *} p<0.001$, significantly different from other mice in the same part of intestine. For abbreviations, see Tables 1 and 2.

greater $(p<0.01)$ than that of the other mice.

$\mathrm{TN}, \mathrm{PN}$, and WIN of gastrointestinal contents per $100 \mathrm{~g}$ of body weight are shown in Table 4. The TN and PN of stomach contents of WECV mice had the 
highest values and AAGF mice showed the lowest WIN $(p<0.01)$. When the small intestine was divided into three parts equal in length, the highest levels of TN, PN, and WIN were generally found in the upper small intestinal contents. The lower part showed the lowest values, irrespective of diets or absence of intestinal microbes. The TN of the contents in the upper part of the small intestine of WEGF mice was high $(p<0.01)$ and the WIN of WECV mice was higher than that of the other mice $(p<0.02)$. The $\mathrm{TN}$ of the contents of the middle part of the small intestine from WEGF mice was high, but there were no differences between the WECV and WEGF mice. PN in mice fed on WE was higher than that of mice fed on AA $(p<0.01)$ and the WIN of AAGF mice was the lowest $(p<0.05)$. The TN and PN of the contents of the lower part of the small intestine from WEGF mice showed the highest values $(p<0.001)$. The WIN values of all mice were almost zero, but the WEGF mice showed high values $(p<0.01)$. The TN of the whole small intestinal contents of WEGF mice was the highest $(p<0.001)$ and the PN of WEGF and CV mice was higher $(p<0.001)$ than that of AAGF and CV mice, but there were no differences between GF and CV mice fed on the same diet. The WIN were not significant as in the case of $\mathrm{PN}$.

The TN, PN, and WIN of cecal contents of WEGF mice showed the highest values $(p<0.05)$. The TN of colon and rectal contents of WEGF mice was high, and the PN and WIN of WECV mice was higher. In all of the gut contents from the stomach to the rectum, the TN of WEGF mice was the highest $(p<0.001)$ and showed significant differences in each group. The PN also had the same tendency as TN, but there were no differences between AAGF and CV mice. The WIN was the highest in WECV mice. Generally, the amount of $\mathrm{N}$ in gut contents of GF mice was higher than in those of CV mice, and the WE diet group had a high value, as seen in Table 3.

In the case of PN per $100 \mathrm{mg}$ of TN of gut contents (Table 5), WECV mice showed high values $(p<0.02)$ in stomach contents. The values decreased in accordance with passage through the small intestine, and in the lower part, low values were shown in all of the mice. In the whole small intestinal contents, CV mice showed values higher than those of GF mice. Cecal and colon and rectal contents of WECV mice showed higher values $(p<0.001)$. In the whole intestinal contents from the stomach to the rectum, WECV mice also had higher values $(p<0.02)$ than the other mice and the absence of intestinal microflora exerted more of an influence than did the difference in diets.

In the case of WIN per $100 \mathrm{mg}$ of PN of gut contents (Table 6), the cecal contents of CV mice was higher $(p<0.05)$ than that of GF mice and the same tendency was also seen in the colon and rectal contents. In the whole intestinal contents, higher values were observed for $\mathrm{CV}$ mice than for GF mice.

$\mathrm{TN}$ of the gastrointestinal tract without contents per $100 \mathrm{~g}$ of body weight is shown in Table 7. CV mice showed higher values than GF mice in the stomach. TN of the small intestine when divided into three parts equal in length was the highest in the upper part and the lowest in the lower part in all of the mice. The values for 


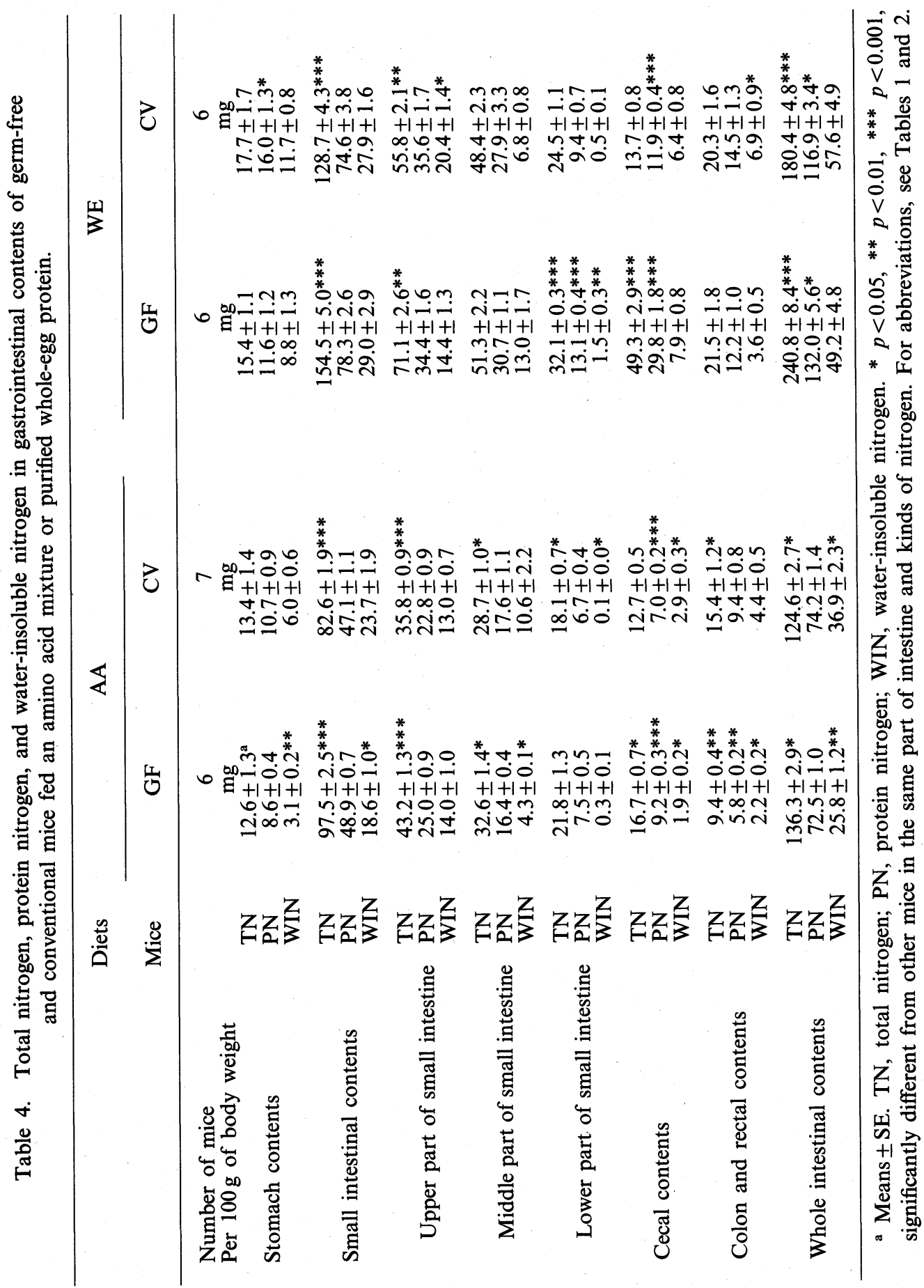




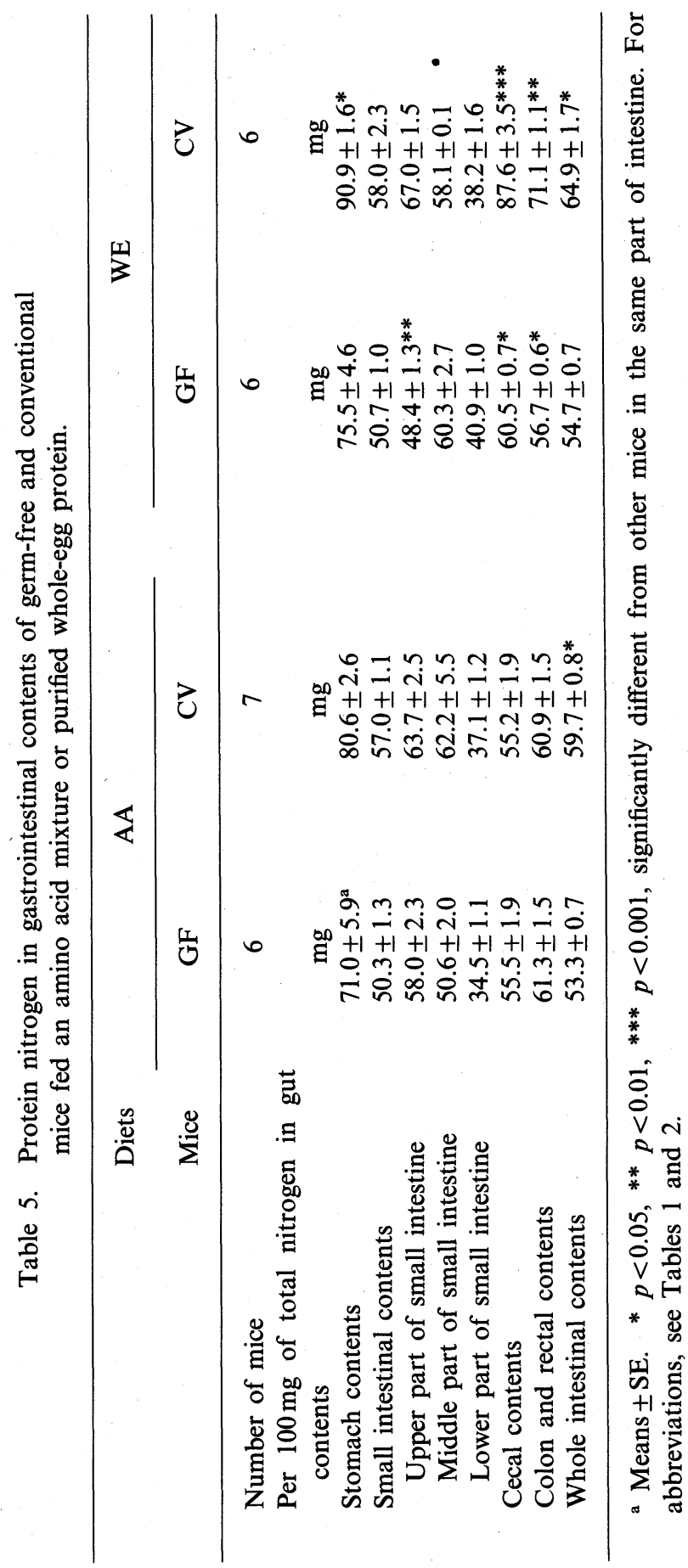




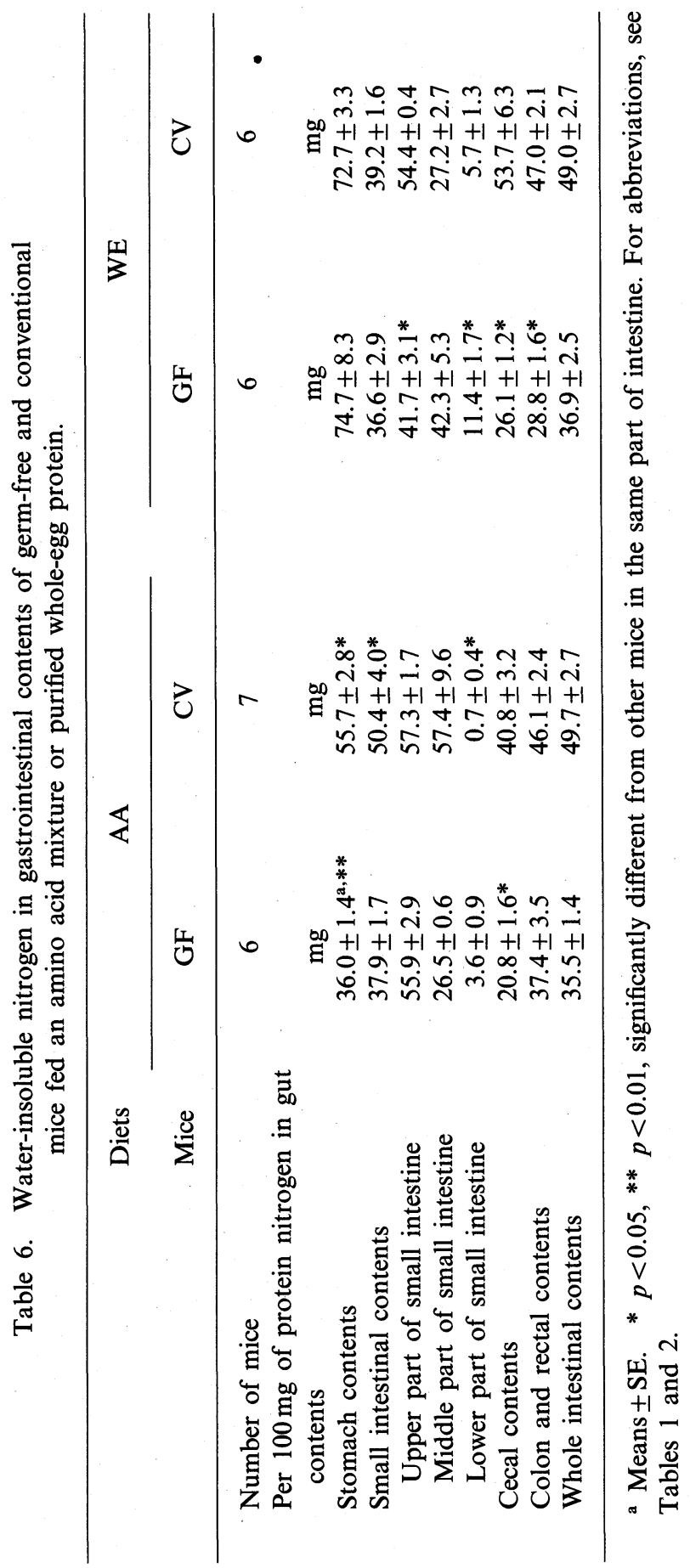

J. Nutr. Sci. Vitaminol. 


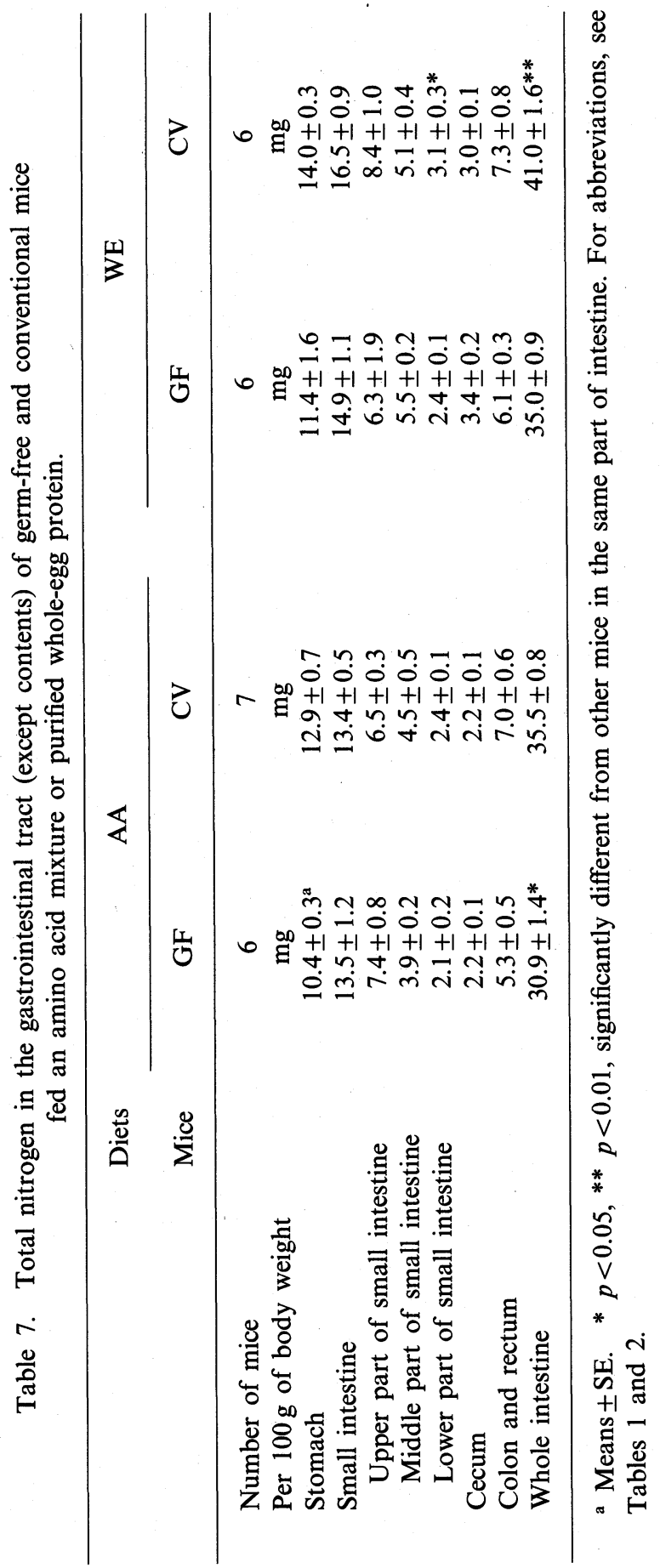

Vol. 26, No. 5, 1980 
the cecum of WE diet-fed mice were higher than those of the AA diet-fed mice $(p<0.01)$, but there were no differences between GF and CV mice fed the same diet. From the stomach to the rectum, WECV mice showed the highest values $(p<0.01)$.

\section{DISCUSSION}

In this experiment, AA or WE diets were given ad libitum for three weeks to male ICR strain GF and CV mice. In the first week, the mice showed the same body weight gains, but after two weeks, WEGF and CV mice showed gains lower than with the AA diet group. The reasons for above were not clear, but the WE diet had a different mixing order as compared with the AA diet, i.e., in the WE diet, the salt mixture was added to corn oil initially but in the AA diet, the salt mixture was added after other materials were admixed. In the previous experiments $(9,10)$, there were no such tendencies even though the WE diet had the same composition as in this experiment.

Individual fresh weights of the cecum of six GF mice fed the AA diet (Table 3) were as follows: $1.76,1.86,1.97,2.07,2.26$, and $2.50 \mathrm{~g}$ per $100 \mathrm{~g}$ of body weight. The fresh weight of the small intestine and whole intestine from the stomach to the rectum, and the length of the small intestine in AA diet-fed mice were smaller than those in WE diet-fed mice and the rate of constriction in the above three cases from WE to AA was almost the same in GF and CV mice. However, the cecum of AAGF mice was constricted to about half of that of WEGF mice. Fresh weights of the stomach and colon and rectum might be influenced by food intake or fecal excretion just before sacrifice. Conversely, there might be no direct effect on the weight of the small intestine and cecum, as when the weight of cecum per $g$ of small intestine was calculated, the values for AAGF mice were closer to those of CV mice than to those of WEGF mice. The TN and PN of gut contents per $100 \mathrm{~g}$ of body weight showed the same tendencies as did the results of the fresh weight of the intestine including contents. For example, in a comparison of the results of fresh weights in Table 3 and TN of the gut contents in Table 4 for the cecum, AAGF mice showed about fresh weights lower by $54 \%$ and content TN lower by $66 \%$ as compared with WEGF mice. However, the CV mice showed lower values of only about $21 \%$ for fresh weights and $7 \%$ for content TN. Next, in a comparison between GF and $\mathrm{CV}$ mice fed the same diet, the fresh cecum weight of AAGF mice was 1.8 times that of $\mathrm{CV}$ mice, but in WE diet-fed mice, the figure was 3.0 times. The TN of cecal contents of AAGF mice was 1.3 times that of CV mice and in the WE group, it was 3.6 times. From these results, it can be considered that the intestine, especially with regard to the cecum, of AAGF mice was constricted more than that with WEGF mice. Moreover, fresh cecum weights or TN of cecal contents per $100 \mathrm{~g}$ of body weight of WEGF and CV mice in these experiments were almost the same as in the previous report (6) when the mice were given the natural type of CL-2 diet. 
In the experiment with GF mice and rats by Sacquet et al.(12), the cecal weight differed according to the kind of diet. The weight of the small intestine of GF and CV chicks fed on natural diet was greater than that of purified diet-fed chicks, and GF chicks showed larger values than CV chicks fed on the same $\operatorname{diet}(13)$. Hashimoto et al.(14) reported that the cecal weight of antigen-free dietfed GF mice was $2.79-2.89 \mathrm{~g}$ per $100 \mathrm{~g}$ of body weight compared with $4.74-5.73 \mathrm{~g}$ for autoclaved CL-2 diet-fed GF mice. The TN of each part of the intestine after removal of contents showed no differences due to the absence of microbes or differences in the $\mathrm{N}$ source in diets in this experiment. These were similar to the results of the TN of the cecal sac (6) and the TN of each part of the intestine(7) of mice given the autoclaved CL-2 diet.

From these facts, the enlargement of the cecum due to the absence of intestinal microbes can be improved by giving the AA diet without the aid of intestinal microbes. Animals were utilized after degradation of dietary $\mathrm{N}$ from protein to amino acids by the action of several enzymes. Enzymes for proteolysis had no opportunity to act except on the secreted endogenous PN in the gut when given the AA diet. It is well known that in GF rodents and rabbits, the intestinal walls are longer and the contents accumulate so that the transit time is slower than that in $\mathrm{CV}$ animals. One possible reason which can be considered is that certain materials produced by the action of enzymes on the food protein in the small intestine cause the enlarged cecum in GF rodents and rabbits. In CV animals, the above materials might be transformed by the action of intestinal microbes.

With respect to amounts of $\mathrm{N}$ in gut contents, GF mice showed higher values than those of CV mice and the WE diet group had higher values than the AA diet group. PN(mg) per $100 \mathrm{mg}$ of TN and WIN(mg) per $100 \mathrm{mg}$ of PN of gut contents were calculated to clarify the influence of the absence of intestinal microbes or the difference in $\mathbf{N}$ source in diets on $\mathbf{N}$ composition of gut contents. WIN might contain something which cannot pass through filter paper, such as hair, fragments from the intestinal mucosa or undigestible food residue. However, in the AA diet group, there was no undigestible food residue present because the PN or WIN of the AA diet could not be analyzed by the same method as used in this work. $\mathrm{PN}(\mathrm{mg})$ per $100 \mathrm{mg}$ of TN of cecal and colon and rectal contents of WECV mice showed high values. This tendency agreed well with the results of previous experiments using natural-type CL-2 $\operatorname{diet}(7,8)$ but the values of AACV mice were almost the same as those of AAGF or WEGF mice. Next, for WIN(mg) per $100 \mathrm{mg}$ of PN of cecal and colon and rectal contents, CV mice showed higher values than those of GF mice for both diets. In the experiments of Chen et al. (15) on the nature of the gut contents where casein, zein, amino acid, $\mathrm{N}$-free and gelatin diets were given to $\mathrm{CV}$ rats, $\mathrm{N}$ in the insoluble residue of gut contents of zein dietfed rats was especially high and casein and amino acid diet-fed rats gave low values. Tricholoroacetic acid-precipitable $\mathrm{N}$ of gut contents showed no differences among the diets. The $\mathrm{N}$ aspects of gut contents in this experiment showed several tendencies in various parts of the intestine, but in general, the absence of intestinal Vol. 26, No. 5, 1980 
microbes had more influence than did the difference in $\mathrm{N}$ source in the diets.

The authors are grateful to the Kyowa Hakko Kogyo Co., Ltd., for their supply of crystalline amino acids and to Miss R. Kato, N. Minamikawa and M. Yoshida, students of Kyoritsu Women's University, for their helpful analyses of samples. An outline of this work was given at the Twelfth Annual Meeting of the Japanese Association of Germ-free Life and Gnotobiology in January, 1979 in Isehara and the Thirty-Third Annual Meeting of the Japanese Society of Food and Nutrition in May, 1979 in Tokyo.

\section{REFERENCES}

1) Yamanaka, M., Iwai, H., Saito, M., Yamauchi, C., and Nomura, T. (1972): Influence of intestinal microbes on digestion and absorption of nutrients in diet and nitrogen retention in germ-free, gnotobiotic and conventional mice. I. Protein and fat digestion and nitrogen retention in germ-free and conventional mice. Jpn. J. Zootech. Sci., 43, 272-283.

2) Yamanaka, M., Iwai, H., Saito, M., Yamauchi, C., and Nomura, T. (1972): Influence of intestinal bacteria on apparent biological value of protein in diet. Jpn. J. Germfree, 2, 56-60.

3) Yamanaka, M., Iwai, H., Saito, M., Yamauchi, C., and Nomura, T. (1973): Influence of intestinal microbes on digestion and absorption of nutrients in diet and nitrogen retention in germ-free, gnotobiotic and conventional mice. II. Protein and fat digestion and nitrogen retention in monocontaminated gnotobiotic mice. Jpn. J. Zootech. Sci., 44, 380-387.

4) Yamanaka, M., Iwai, H., Saito, M., Yamauchi, C., and Nomura, T. (1973): Influence of intestinal microbes on digestion and absorption of nutrients in diet and nitrogen retention in germ-free, gnotobiotic and conventional mice. III. Protein and fat digestion and nitrogen retention in polycontaminated gnotobiotic mice. Jpn. J. Zootech. Sci., 44, 388-396.

5) Yamanaka, M., Saito, M., Yamauchi, C., and Nomura, T. (1973): Influence of autoclaving of diets on digestibility of nutrients and nitrogen retention in conventional mice. Exp. Animals, 22, 5-14.

6) Yamanaka, M., Takahashi, H., Ishihara, T., Iwai, H., and Saito, M. (1973): Nitrogen in the cecum and the kidneys in germ-free, gnotobiotic and conventional mice. Exp. Animals, 22, 257-262.

7) Yamanaka, M., Nomura, T., and Kametaka, M. (1974): Role of intestinal microbes on body nitrogen accumulation in germ-free, gnotobiotic and conventional mice. J. Nutr. Sci. Vitaminol., 20, 389-400.

8) Yamanaka, M., Nomura, T., and Kametaka, M. (1977): A comparison of intestinal contents in germ-free and conventional mice. Environ. Control in Biol., 15, 11-16.

9) Yamanaka, M., Nomura, T., and Kametaka, M. (1977): Role of intestinal microbes in body composition in germ-free, gnotobiotic and conventional mice. J. Nutr. Sci. Vitaminol., 23, 211-220.

10) Yamanaka, M., Nomura, T., and Kametaka, M. (1977): Influence of intestinal microbes on heat production in germ-free, gnotobiotic and conventional mice. J. Nutr. Sci. Vitaminol., 23, 221-226.

11) Yamaguchi, M., and Kandatsu, M. (1973): Nutritional evaluation of dietary proteins with regard to body protein metabolism in adult rats using purified whole egg protein as a standard reference. Agric. Biol. Chem., 37, 809-817. 
12) Sacquet, E., Lachkar, M., Mathis, C., and Raibaud, P. (1973): Cecal reduction in "gnotoxenic" rats, in Germ-free Research (Biological effect of gnotobiotic environment), ed. by Heneghan, J. B., Academic Press, New York and London, pp. 545-552.

13) Coates, M. E. (1977): The influence of the microflora on the physiology and function of the gut. Proc. Jpn. Soc. Anim. Nutr. Metab., 21, 110-119.

14) Hashimoto, K., Handa, H., Umehara, K., and Sasaki, S. (1978): Germ-free mice reared on an "antigen-free" diet. Lab. Anim. Sci., 28, 38-45.

15) Chen, M-L., Rogers, Q. R., and Harper, A. E. (1962): Further observations on the gastrointestinal contents of rats fed different dietary proteins. J. Nutr., 76, 235-241. 